\title{
Computerized Approach towards the Standardization of Dental Dossier in the Field of Forensic Investigation
}

\author{
Amit Chauhan* \\ Amity Institute of Forensic Sciences, Amity University, India
}

Submission: November 23, 2017; Published: February 05, 2018

"Corresponding author: Amit Chauhan, Amity Institute of Forensic Sciences, Amity University, Uttar Pradesh, India, Tel: +91-9540067484;

Email: amit_chauhan777@yahoo.in

\begin{abstract}
In the modern world of advancement, the revolutionary technology is waving very fast in every field. The field of criminal justice system is also influenced by this advancement of science that has made the changes in the crime detection and investigation techniques. The prior responsibility of the investigation is to convert the doubt into reasonable certainty of the suspect either guilty or the innocence which require a lot of efforts to discover the root cause of crime. Generally, the investigation ended up by the adoption of the unfair and illegal means. The intersection of law relay on the scientific evidences which can be scientifically proved. These continuous changes will flourish the scientific technology if the odonatological data could be preserved for further query.
\end{abstract}

This data can be used by the investigators for the investigation in case of mass disasters, accident and in case of skeleton remaining. These techniques have helped to be a great assistance in many cases in gathering the information from the suspects. In this study, we focused upon the centralization of odonatological data and the capitalization of this computational technique in forensic investigation. It can prove the crime of the suspect beyond all reasonable suspicion and can protect the innocent from wrong conviction in criminal jurisprudence.

Keywords : Advancement; Science; Investigation; Detection; Suspects; Dental data

\section{Introduction}

In the modern era of advancement and technology, the advancement has changed the work process, data storage and investigation mean. Now a day, the identity of an individual has been stored in digital form. Digitalization has made it easy to access and get information about anyone from anywhere. It has been estimated that by use of a computer, there were over 2 billion possibilities in the charting of adult dentition [1]. Therefore, it would rule out the possibility of two adults having exactly the identical dentition. Although, identification of an individual by teeth marks is not a new technique yet its utilization to criminal justice system is in advancement [2]. Teeth are highly resistant to destruction and decomposition, effects of adverse environmental conditions e.g. air, water, extremes of temperature, dental identification thus it can only be made under extreme circumstances [3].

Human bite marks are found when teeth are used as weapons in form of anger; weapons of excitement; weapons of control or weapons of destruction. It can be found in food, flesh, cigars, pipes and musical instruments etc. Bite marks are usually encountered in shape of semi-circular or crescentic, caused by the front upper and lower incisors [4,5]. These marks could be separate, clear, continuous or in form of an intermittently broken line. Bite marks may be abrasions, contusions or lacerations or a combination of any two or three. Rarely, the bite mark may be linear in pattern, due to the scraping of the skin by the upper incisors, causing parallel tracks. Bite marks are unique and forensic dentists are able to make a cast or photograph of the bite marks by means of comparison from the suspects data.

\section{Confrontation of Dental Dossier}

During the natural disasters e.g. flood, earth- quake, hailstorm etc. aero plane crash and un-identified dead bodies putrefied or decomposed dead bodies; the identification of deceased become complicated for investigators. Only partial body fragments, bones remain and teeth are recovered from the crime scene which reveals the information about an individual based on DNA fingerprints [6]. This technique is costly and not possible to apply in every case. The teeth, that carry information about the deceased like age, gender etc. could be useful to establish the identity. The information about every patient that is recorded in the computer by their concern doctor, if this dental dossier could be centralized, then it will become very easy to get the information about the deceased from dental information [7].

Bite marks are frequently encountered in sexual assault cases from the body (cheek, thigh, breast, hand etc.) of the victim. During the struggle with culprit, the victim uses to bite the culprit and dental formation of victim transferred over his/ her body part. Bite marks sustain for a time duration only the 
size proportion change and colour while rest of the information could be retrieved (abnormalities, shape and size of teeth, etc.) from the body parts of victim/ culprit.

In a few cases of kidnapping or attempt to murder, the victim tries to get rid off from the culprit and implement their bite marks over the body of culprit [8]. Due to darkness or other circumstantial condition, if the face of culprit was not recognized in those cases; the suspect persons are minimized based on doubt and confirmed by examining/ presence of bite marks. In cases of burglary, the criminal teeth marks can be recovered from the food stuffs like, fruits, vegetables, fast food etc. However, the dental information is not an accurate representation of teeth because it depends upon the position of jaw, movement and use of tongue [9].

\section{Aspects in Investigation}

With the rapid advancement in odontology, new methods and guidelines have been formulated. These guidelines are considered dynamic and are being modified as significant development evolves so that the quality of investigation could be enhanced. By the time of developing digital data, the challenge is that data is likely to be stored in an old or even obsolete format [10]. It will be a great achievement in forensic investigation as well as for establishing identity of an individual. Every year in India, 2,22,446 unidentified dead bodies, 73242 women and 33825 children are reported missing. It becomes very difficult to search the missing or to get any information regarding to them, it will prove its worth. In burnt cases where only lower jaw or teeth are recovered, it will become easy to identify the person gender and age with instance that will save the time for investigation.

A patient having any kind of dental disease/ abnormalities who may be going under treatment, if shifts from one place to another; can provide the information at another place to anyone. This digital dossier will share information such as age, gender, address, contact details and the history of their treatment. In other aspects of investigation i.e. sexual assault, the dental formation can be examined from the skin and preserved in digital form which could be match with the centralized dentine dossier. It will minimize the number of suspect and save time. Eatables items (fruits \& vegetables), which bear the teeth marks can decrease in size and shape with time but, it will carry the dental information of the suspect.

A portable device or electronic system that can be used to store the dental data in the designed algorithm present on various objects or surface. The algorithm will convert it into binary form and will get the match of it from the dossier file. If the data will exist in system, it will provide the information about the suspect/culprit or it will be recorded in the system. If in future similar kind of bite marks is encountered from any other scene of occurrence, it will match with the previous stored data. The culprit if ever will meet with any dentist anywhere throughout the country and the profile will update. Immediately, the earlier record will match to it and an alarm will give a ring to controller about the information about the culprit's details. It may be slight delay by the time to recording of details of culprit but, will provide great assistance to the investigators to nab the suspect and put them behind the bar. This system will be beneficial for crime investigation and legal justice system.

\section{Conclusion}

Now a day, digitalization has taken place in our society and we are totally dependent on it from a minutiae detail to everything that includes transact, interaction, appointment, international travel, biometric system, criminal history etc. The benefits are obvious but along with the security implication too such as to provide the information about the work place, address and other details to a non-governmental person who can cause problem to the person. Since, digital dentistry is causing a revolution all over the world just like other technologies as fingerprint biometric, retina, voice identification etc. the amount of details that are required in a functional and aesthetic planning makes the dentistry check-list larger according to the needs of treatment. In earlier phase of dentistry, this concept was developed to join any kind of similarities and bring the most important parameters to the digital environment, allowing a fast and complete vision. This same technology needs to be centralized at government level to provide its significance in investigation or missing person complain. If this implementation could be done, it will be very helpful to get information about anyone and to do the needful as per the requirement.

\section{References}

1. Scroll (2017) Privacy, security and legality are not the only serious problems with Aadhar. Here are four more.

2. Business today (2017) Aadhar privacy; Key issues that all aadhar card holders should bear in mind.

3. Allonmoney (2015) 17 Benefits of aadhar card, why it is mandatory, important uses.

4. Deivedi Nidhi, Agarwal Akhil, Kashyap Bina, Raj Vineet, Chandra Shaleen (2013) Latent lip prints development and its role in suspect identification. Journal of forensic dental science 5(1): 22-27.

5. Sivapathasundharam B, Prakash PA, Sivakumar G (2001) Lip prints (Cheiloscopy). Indian J Dent Res 12(4): 234-237.

6. Whittaker DK, MacDonald DG (1989) A colour atlas of forensic dentistry. Wolfe, London, P. 55-60.

7. Hirth L, Göttsche H, Goedde HW (1975) Lip prints-variability and genetics, Humangenetik 30(1): 47-62.

8. Amit Chauhan, Aditi Chauhan, Jyoti Singh, SK Shukla (2017) A correlative study between the implementation of rhythmic system and the hieroglyphics substantials. Int J of Current reserah and review 9(9): 1-5.

9. Gungadin S (2007) Sex determination from the fingerprint ridge density. Internet Journal of medical Update 2(2): 4-7.

10. Moore RT (1994) Automatic fingerprint identification systems, Advance fingerprints technology, Lee HC CRC press, India. 

(C) (C) $_{\text {BY }}^{\text {This work is licensed under Creative }}$
Your next submission with Juniper Publishers will reach you the below assets

- Quality Editorial service

- Swift Peer Review

- Reprints availability

- E-prints Service

- Manuscript Podcast for convenient understanding

- Global attainment for your research

- Manuscript accessibility in different formats ( Pdf, E-pub, Full Text, Audio)

- Unceasing customer service

Track the below URL for one-step submission https://juniperpublishers.com/online-submission.php 